\title{
Rationalist tendencies in the translation of Slovak historiography into English
}

\author{
Danica Maleková \\ Catholic University, Slovakia \\ danica.malekova@ku.sk
}

\begin{abstract}
The paper investigates how dominant epistemic frames backed by the methods of materialist science appropriate a translated text, thus changing its imagery and patterns of meaning. It discusses the language / culture determinants in the process of translation and relates the findings to the tendency towards hegemony in understanding what constitutes legitimate knowledge representation. Employing the tools of the cognitive approach to translation, the analysis is based on a case study of a translation of a Slovak historical text into English. More specifically, the paper explores translation of verbs related to the historical agents and their symbols. The cognitive framework accommodating the analysis shifts the perspective to the imagery invoked, and it is shown that the original imagery is significantly reduced in the target text. The analysis tracks the reductionist processes down to schematization, or what could be called abstractification, with an effect of disengaging the reader from the scene, as well as renormalization of agency, whereby semantic relationships are conventionalized. It is argued that such reduction is not a 'natural' process, nor is it necessitated by the variation in the target language structure, and it ultimately serves ideological ends.
\end{abstract}

Keywords: rationalism, abstractification, knowledge representation, historical agents, translated historiography 


\section{Introduction}

The epistemic framework guided by scientific rationalism and empirical positivism is being seriously undermined an increasing range of fields of human activity. In the area of translation studies, Tymoczko (2002: 22) points to the growing realization that in fact all scientific research is subjective as it relies on certain "frames of reference, interpretation, mental concepts and received meanings".

Notwithstanding the impact of epistemic challenges triggered largely by the developments in physics, it can be claimed that the neoliberal ideology with its Cartesian worldview still constitutes the dominant framework, and, by defining the legitimate meaning patterns, aspires to hegemony. As pointed out by Bennet (2007a: 191),

[b]olstered by capitalism and technology, the scientific worldview at present determines what might legitimately be considered as knowledge, and its gatekeepers [...] ensure that aliens are either domesticated or kept out.

In this connection, Verschueren (2012: 9) speaks about ideology as meaning in service of power, which serves as a tool in the hands of dominant classes "to avoid coercion by obtaining the consent of the oppressed, i.e. by successfully making certain patterns and frames of interpretation ... seem natural" (Verschueren, 2012: 11). Appreciating the social basis of ideology, he postulates that

[t]he wider the society or community, and the wider the range of discourse genres in which a given pattern of meaning or frame of interpretation escapes questioning, the more 'hegemonic' it may be. (Verschueren, 2012: 13)

Inasmuch as there is an intricate connection between culture and language, this would imply that any translation into English as the main language of globalization will be more prone to serve the hegemonic tendencies than a translation in the opposite direction. It is thus only natural that the question of power relationships features prominently in Anglo-American thought on translation, with Venuti as one of its strongest proponents. Venuti (1995: 20) describes much of the practice of translation into English as dominated by what he calls domesticating strategies:

By producing the illusion of transparency, a fluent translation masquerades as true semantic equivalence when it in fact inscribes the foreign text with a partial interpretation, partial to English language values.

In this way, translation becomes a tool for appropriating meaning to fit uniform frames as defined by the target culture dominant values, a process that not only endangers the vitality of value systems tied to minor cultures, but, in consequence, the balance sustained by the diversity. It is from this perspective that hegemony equalled to the dominance of one ideology is undesirable as much as it is dangerous. 


\section{Hegemony, translation universals and cognitive translatology}

In the area of language and its use, what is the hegemonic discourse that casts its spell over the majority of academic endeavours characterized by? Associated with what Venuti (1995: 5) calls the 'authoritative plain style', it strives for clarity marked by explicitness and absence of ambiguity, coherence, structured rational argument supported by impartial evidence, objectivity and impersonality (cf. Bennet, 2007b: 152). Figures of speech or any other ornamental language should be avoided. However, do not these qualities correlate with universal tendencies in any act of translation?

Halverson (2013: 49) lists simplification, explicitation, normalization or conservatism and levelling out as candidates for translation universals. Similarly, Mauranen and Kujamäki (2004) hypothesize the influence of universals in the process of translation, with simplification and explicitation in the forefront. The generalizations are supported by various studies on translation shifts - higher proportions of grammatical words and high frequency words in translations were detected by Laviosa (1998); less diverse collocation patterns were identified by Dayrell (2007) and Balaskó (2008) to give but a few examples.

However, the methodology by means of which the postulates are arrived at as much as the practice itself might be influenced by the Western values and the fact that the majority of the studies look into translation between European languages. This would specifically hold for the theories based on the functionalist approach, as noted by Muñoz Martín (2013: 81), who claims that functionalist translatologies 'ground the notion of translating in Western traditional, folk-psychological theories of instrumental rationality'. Tabakowska's (2013) study of the translation of a poem by Emily Dickinson actually demonstrates that the translator has brought richer and more detailed imagery is brought into the Polish version of the poem, which would hardly concord with the universals as evidenced by the quantitative studies carried out so far.

In fact, if the perspective of cognitive linguistics (CL) is brought to enrich translation theory, the notion of translation universals becomes even less clearly defined and largely unsupported as it replaces the focus on functional/contextual features of the linguistic signs with the study of the construals related to the ability of the human mind to use imagery to construe the situation in alternate ways (cf. Langacker, 2009). Such indeterminacy of grammar and the inherent subjectivity of meaning are premises that might be more adequate to respond to the challenges put forward by the epistemic perspectives now sprouting. The validation of subjectivity and bodily basis of meaning contradicts the argument that reducing the richness of meaning in the service of technocratic uniformity is an inevitable and natural process, let alone a desirable one.

In the framework of cognitive translatology, translational act is understood as "activation and selective use of several particular kinds of knowledge filtered through the cognitive process" (Rojo, 2013: 13). Equivalence is thus based on activating similar conceptual frames (Rojo, 2002). Here, the central role is played by imagery triggered by situated imagination (cf. Martín de Léon, 2013: 113), as it is fundamental to 
understanding. Consequently, if the translator changes the imagery, the reader will have a different understanding. If the frames applied in the process of translation are accountable to a certain ideology, then the resulting meaning patterns will be supplied by the respective ideology rather than by reproducing the original experience, because, as asserted by Verschueren (2012: 14), ideology "may be highly immune to experience and observation". As a knowledge filter, the dictate of an ideology can actually change what counts as schema-refreshment into schema-affirmation (Jeffries, 2010: 132-133), or reduce what Hatim and Mason (1997: 27) call 'communicative turbulence' to stable and predictable patterns.

Rather than assuming that the process of translation is always ipso facto observant of translation universals, it can be perceived as a potential tool to resist them, or a "weapon against hegemonic powers" (House, 2005: 23). To work in this way, translation needs to rely on the inherent subjectivity of the representation of the text in the translator's mind. The imagery thus arrived at would provide the grounding for the process of translation and replaces the notion of invariant given by the function the text should serve in the target culture.

In reference to translation, it is not unreasonable to assume that a visualization might also arise in the translator's mind to function as the notorious tertium comparationis involved in the translation process. (Tabakowska, 2013: 231)

Thus the degree to which individual translators are able to and/or allowed to gain complex and informed access to the imagery triggered by the source text is the degree to which collective ideologies might be defied. As House (2005: 210) points out, "[s]peakers are not imprisoned by the language they speak. There is always an escape through the creative potential of language itself, and through the creativity of its users".

The central place of imagery in cognitive translatology is grounded in the basic tenets of cognitive linguistics, where imagination is perceived as the fundamental mechanism for the production of any meaning and rationality. In their seminal work, Lakoff and Johnson (1999) ground any complex thinking in metaphoric projections that can be traced to the way human bodies function in the world. It is therefore impossible to draw a clear line between the concept of imagery operating in everyday language and imagery as a creative linguistic process (cf. Rojo, 2013: 8). This in fact deletes a clear distinction between the artistic (literary) and other (non-literary) use of language, including, necessarily, the discourses of art and science as their respective manifestations.

\section{Science versus art}

Blurring the distinction between the literary and non-literary uses of language is not an entirely new avenue of thought, as Snell-Hornby's (1995) 'prototype' approach where the categories literary and non-literary form a continuum can be brought to witness. In fact, Snell-Hornby preserves the distinction, as, supposedly, there are prototypical 
specimen, or better or worse representatives of various text genres. However, what the continuum approach brings into spotlight are the borderline cases dwelling on the intersections, and these cannot be simply excluded to make our classifications neat.

In fact, Halliday (1994/2001: 143) speaks of two value systems applying to scientific writing and a work of literature, with the scientific one privileging ideational meaning and uniformity of the system, and the humanistic one highlighting interpersonal meaning, uniqueness and diversity of natural processes. Notwithstanding the distinction, he makes an allowance for in-between cases, granting them legitimacy in both contexts:

There are some texts which by their own birthright lie at the intersection of science and verbal art: which are not merely reconstituted in this dual mode by us as readers, but are themselves constituted out of the impact between scientific and poetic sources of meaning. (Halliday, 1994/2001: 144)

Taking the point of view of value systems and competing ideologies, the debate boils down to whether what Halliday (1994/2001: 144) calls 'poetic sources of meaning' is allowed as a legitimate element in the process of encoding objective knowledge. In the field of translation studies, what we are actually asking is whether translators are allowed to strip academic source texts of their poetic aspects of meaning in the name of science as defined by the Western values and what is actually the ethos that is served thereby.

Throughout the present paper it is hypothesised that by weakening unconventional imagery unique to the author of the text, not only the goal of translation equivalence as defined in the framework of cognitive translatology is compromised, but, what is worse, hegemony related to the existing power relations is unduly reinforced, with the very 'diversity' niche colonized by the uniformity of the dominant value system. The aim of the case based analysis offered below is to track some of the persistent linguistic patterns which feed such appropriation.

\section{The analysed text}

The text selected for analysis was written by L'ubomír Lipták, one of the most respected historiographers in Slovakia whose theoretical work managed to surmount the barriers of the totalitarian regime. As a consequence, Lipták was expelled from the Slovak Academy of Science and the publication of his works was restricted for almost 20 years. It is partly the deep questioning of the communist ideology that charges Lipták's texts with a sparkle of fruitful polemics, complex and problematizing insights into the workings of the system, or dialogic character in Bachtin's sense.

In opposition to formal and distanced objectivity typical of the scientific discourse, Lipták's texts display a subjective touch. The reader is constantly reminded of the author's subtle self-irony that actually transcends his individual personality to become something of a national characteristic. Reverberating on the humour of his literary 
contemporaries such as Rudolf Sloboda or Pavel Vilikovský, it represents a tactic through which a small nation is trying to come to terms with its entrapment in a history of subjugation. In fact, this position stands against other frequently exploited strategies represented by pseudopatriotic or sentimental historical interpretations.

Lipták's text Rošády na piedestáloch [Castlings on piedestals] provides a systematic account of the shifts of power symbols throughout the $20^{\text {th }}$ century Slovakia. Lipták describes how susceptible the idols people worship are to changes of ideology. Great heroes are raised and knocked down from plinths as need be, high ideals are dressed into low materiality. No one ends up in sanctity. Historical personalities are presented as caricatures, carnal little figures that mirror our own helplessness. All of this is masterfully rendered by specific use of language, ranging from first person accounts to a comic portrayal of the events. It can thus be stated that the text stands on the intersection between science and art in the sense suggested above.

As will be demonstrated by the analysis, in her English translation titled Monuments of political changes and political changes of monuments, S. Miklošová largely downplays the 'artistic' dimension, thus redirecting the sources of meaning towards values such as uniformity and normalcy.

\section{The 'pull' of the genre prestige}

As genres and their prestige might be one of the determinants in the process of translation, an excursion into the position of the genre of the analyzed text - an essay in the cultures concerned should be made at this point.

The Anglo-American prejudice against the essay as a genre striving for factual credibility can be glossed by looking at the Webster dictionary definition, where 'essay' is

an analytic, interpretative or critical literary composition usu. much shorter and less systematic and formal than a dissertation or thesis and usu. dealing with its subject from a limited often personal point of view (Webster's Third New International Dictionary of the English Language (1993)) (emphasis added)

The evaluation inherent in the definition highlights a downgrade in systematicity and formality compared to affiliated genres, as well as inferiority in the breadth of perspective. Its adjectival derivative 'essayistic' follows suit, implicitly positioning the essay below its generic competitors in terms of seriousness, as

more informal, discursive or personal in its exposition of an idea than a dissertation or a treatise (Webster's Third New International Dictionary of the English Language (1993)) (emphasis added) 
The dictionary evaluation is commensurate with the one that can be found in Routledge Dictionary of Literary Terms, where the essay is, again, belittled in terms of credibility compared to alternative forms:

a polished and sophisticated form of fireside chat, a smooth way of putting over moral reflections, aphorisms and obiter dicta in a less rigorous and rebarbative manner than the treatise or ethical disquisition permits (Routledge Dictionary of Literary Terms (2006)) (emphasis added)

The cultural bias can be evidenced by a comparison to the definition in the Slovak canonic dictionary, where the word 'esej' is delineated as

an artistic reflection on the topical issues of social, cultural, scientific or economic life (the author's translation) (emphasis added)

[umelecky spracovaná úvaha o aktuálnych otázkach spoločenského, kultúrneho, vedeckého al. hospodárskeho života] (Slovník súčasného slovenského jazyka (2006))

Here the inherent evaluation is concentrated in the adjectives 'artistic' and 'topical', which attribute a positive value, rather than a negative one associated with an inferior perspective as is the case with the English definition. Similarly, its adverbial and adjectival affiliates 'esejisticky' and 'esejisticky' highlight the qualities of 'interesting, witty, humorous, and yet as-a-matter-of fact', with no hint at its less serious position in comparison with the related genres.

Explicit positioning of the essay on the scale with other genres, both literary and non-literary, can be traced in Findra's (2004) Stylistika slovenčiny [Stylistics of Slovak] where the essay is enlisted under 'theory' genre models together with the dissertation and the study. Findra's (2004: 212-213) description of the essay accentuates the author's personality and his 'brilliant individual style' with which he treats specialized issues in a 'soulful manner', giving them a fresh evaluation, subjective interpretation, and a new order and perspective. In the process, the writer is not only concerned with the content, but also the form and a cultivated, even ornamental expression. All of this points to a much more positive evaluation of the personal aspect in the Slovak cultural environment compared to its Anglo-Saxon counterpart.

The Slovak attitude might be seen as mirroring the situation in other European countries with strong Catholic tradition such as Spain or Portugal. As claimed by Bennet (2007b: 177) claims,

a whole different attitude to knowledge and discourse has indeed prevailed [in the countries that are] inevitably strongly Catholic, and thus bypassed the Protestant-led scientific revolution that propelled the Northern Europe into the new paradigm.

According to Bennet, the value attributed to 'soulfulness' by a particular culture is the very degree to which genres allowing for subjectivity and emotions, or artistic expression in the most general sense, are granted academic prestige, given the fact that "'soulfulness' [...] is inherently antagonistic to the Cartesian or scientific account of the 
world', as there is 'no valid concept' in the language of science for the 'intangible moral dimension that the religious know as 'soul'"(Bennet, 2007b: 178).

Indeed, while 'soulfulness' associated with the subjective, poetic dimension of the text might be valued in the humanities academic writing in one culture, it can be frowned upon as undermining the scientific validity in the other culture. Therefore, when translating from the former to the latter, the translator might have a motivation (or even a publication order) to re-muscle the text onto a more 'prestigious' skeleton, i.e. his/her translation choices can come under the dictate of the values common to the more 'objective' scientific writing.

\section{The analysis}

The focus of the analysis are verbs related to the activities of the historical personalities as represented by their statues and other ideological symbols such as monuments and commemorative tablets of various kind. Verbs play a prominent role in the selected text, which is given by the lively and dynamic style of the writer and his general approach to the historical material. Another reason for restricting the analysis to the category of verbs is the scope of the present study, as a more encompassing survey would require a much larger space.

In terms of methodology, the research is predicated on the tenets of cognitive translatology, as suggested above, where translation equivalence is understood as equivalence in imagery triggered by the conceptual make-up. This puts shifts of imagery into the foreground of attention. In particular, the level of specificity related to the construals evoked in the reader's mind and the issue of agency should serve as a general guideline for comparing the source and target text.

In order to be able to deal with a fairly extensive text (39 pages in the original version) the method of sampling is employed, where two page samples (Lipták, 1998: $311-312,317-318,349-350)$ are taken from the beginning, the middle, and the end of the source text. The whole selection contains 80 verbs denoting activities related to the heroes and monuments, all of which are translated by verbal structures into the target language. A significant shift in imagery occurs in 25 items, which is almost one third. The shifts share the basic characteristic of creating a distance between the scene and the viewer, enhancing emotional distance and neutralization, and conventionalizing the imagery. The following account will treat the basic outline in more detail.

One of the dimensions of alternate construals of the scene is the level of specificity mapped onto the scale running from the most schematic to the most detailed. This is commensurate with what Langacker (2009: 194-195) terms viewing arrangement, which constitutes one facet of the conceptual substrate related to every linguistic expression. Tabakowska (2013: 234) argues that the level of specificity is "connected with the situation (spatial and/or temporal) of the viewer and the viewed". This, in turn, gives us the parameter of 'distance' (Tabakowska, 2013: 234), as can be demonstrated on the following event representations: 
(1) a. vláda robotníkov a rol'níkov ich zosadila z podstavcov

b. the government of workers and peasants has removed them from their plinths

where on the literal level, the Slovak verb includes the manner of movement, i.e. 'to put down from a high chair/seat'. Arguably, such level of detail can only be perceived when the distance from the scene does not exceed certain level, while the more schematic construal triggered by the English verb 'remove' does not require such closeness.

Being placed at a closer distance, the viewer is more involved in the scene, while zooming out of the situation in the target text provides the viewer with distance and thus more detachment. As pointed out by Sweetser (1991: 39), "the objective and intellectual domain is understood as being an area of personal distance, in contrast to the intimacy or closeness of the subjective and emotional domain". The translation shifts the construal towards intellectualization, or rationalization, as it entails a change in the level of categorization from a basic level category to a superordinate one. From the point of view of imagery, one of the relevant psychological attributes of basic level categories concerning motor movements is that "it is only on the basic level that organisms and objects are marked by characteristic actions" (Ungerer and Schmid, 1996: 69), while the most obvious deficiency of superordinate categories is lack of an 'underlying gestalt that applies to all category members' (Ungerer and Schmid, 1996: 74). On the other hand, their 'collective' function is crucial for scientific work.

The analyzed sample includes 23 verbs expressing motion events used in the literal sense. Out of these, 8 are rendered as less specific in the target language, with the 'manner of motion' deleted from the conceptual structure, thus modifying the nature of imagery making it more schematic. There is not a single case undergoing the opposite process, i.e. zooming in the target language. Apart from the above mentioned example, the respective translation shifts include:

(2) a. Boli dokladom nemeckej pedantnosti, že ich niekde nezapatrošili

b. It was testimony to the Germans' pedantism that they had not misplaced them

In this example, the sememe 'in a careless manner' is missing from the English translation.

(3) a. ležali však a postávali, ktorý ako

b. but some lay and others stood

Here, the sememe 'in an idle manner' is levelled out.

(4) a. Cisár Caligula dal doviezt' do Ríma sochy gréckych bohov

b. Emperor Caligula had statues of Greek gods brought to Rome

where 'means of transport (a wheeled vehicle)' is coded in the source text, while it does not feature in the target text. 
(5) a. pritesat' svoju vlastnú podobu

b. replaced with his own likeness

Again, the specific construal of the manner in which the gods' heads were replaced, i.e. by 'carving onto' is missing in the English version. Interestingly, the use of the same lexical item with the same denotation a line below is already rendered with a greater level of specificity:

(6) a. Aké hlavy pritesali na grécke importy

b. what heads they sculpted onto the Greek imports

where instead of the more down-to-earth connotations of the expression 'carve', which would be a more literal match with the Slovak 'tesat' readily tied to the profession of a carpenter, associations with art or higher forms of human activity are triggered by alluding to the profession of a sculptor. Notably, a word of Latin origin is preferred over an Anglo-Saxon one - a choice that is hardly in accordance with the carnal effect intended in the source text.

(7) a. kde roku 1863 za bližšie neznámych alebo radšej nespomínaných okolností vypadol $\mathrm{z}$ kočiara starosta

b. where in 1863 in almost unknown or rather unmentioned circumstances the mayor fell from his carriage

Here, the internal structure of the Slovak verb consists of the prefix 'vy-' triggering the construal of involuntarily moving out from an inside space and landing on the ground. Although Slovak verbs, given their more complex morphological structure, are generally more concrete and definite than their English counterparts, which tend to be more polysemic, the imagery signalled by the inside-out meaning element provided by the prefix can still be considered marked, especially in comparison with a more neutral 'spadnút', where the prefix 's-' just signals the top-down orientation and finiteness of the movement. Arguably, the imagery of falling out from a closed space produces humorous effect, very much in partnership with the local context, which insinuates that the mayor is drunk ('when returning from the May festivities'). This element is levelled out in the English translation, as the movement is represented in a more schematic way - as though viewed from a larger distance.

(8) a. Hrobmi jednotlivcov, táborov i celých plukov, odvelených neodvolatel’ne na druhý svet.

b. The graves of individuals, battalions and whole regiments posted irrevocably to the other side.

In this case, the Slovak expression is more specific about the agent of the process of 'posting', which is a military authority. The English translation does not feature the concept. 
(9) a. do povedomia dnešných generácií sa dostávajú iba vd’aka tomu, že...

b. they often enter the consciousness of today's generation only thanks to the fact that...

While the Slovak verb activates the construal of 'slowly and with difficulty', which is even emphasized by its imperfective form, the English verb, etymologically a borrowing from French, does not express manner, and is thus more arid in imagery. As there is no adjunct compensation, with the adverb often denoting frequency rather than manner, the event of movement undergoes the process of zooming out.

To tackle the question of whether the tendency of the shifts might be necessitated by the different structure of English language as opposed to its Slovak counterpart, as

[w]ords in a language with a synthetic structure (such as Czech, Slovak) usually have a more definite meaning than words in a language with an analytical structure (such as English or French) (Peprník, 2000: 138)

we can point to Slobin's $(2000,2007)$ research into the semantic properties of verbs coming from different language families. Slobin makes a major distinction between the so called satellite-framed and verb-framed languages (s-languages and v-languages respectively), depending on how manner of motion events is coded. While Germanic languages would be an example of the former, Romance languages would represent the latter:

Manner is highly codable in English, because it is carried by the main verb. Every clause requires a verb, and it is just as easy to say go in as run in. [...] English speakers get manner 'for free', and make widespread communicative and cognitive use of this dimension. In French, by contrast, manner is an adjunct - an optional addition to a clause that is already complete. (Slobin, 2007: 906)

Slobin comes to the conclusion that speakers of s-languages will have 'rich mental imagery of manner of motion' and it will be prominent in memory for events (cf. Slobin, 2007: 907). With regard to translation, referring to the study of translations of a chapter from The Hobbit by Tolkien, he outlines the following tendencies:

Manner verbs tend to be retained in translations into other s-languages: German, Dutch, Russian, and Serbo-Croatian [...] and they tend to be neutralized, diminished, or omitted in translations into verb-framed languages: French, Spanish, Italian, and Portugese; Turkish; and Hebrew. (Slobin, 2000: 124)

Slovak, belonging to the family of Slavonic languages, is, like English an slanguage. This means that the speakers of both Slovak and English will dispose of "rich mental imagery of the manner of motion", and according to Slobin's study the imagery tends to be retained in translations from English to other s-languages, so we can reasonably expect Slovak would be no exception. If this is not the case with Lipták's text, the structural differences in the way the two languages code motion events cannot account for the respective shift of the level of specificity in translation from Slovak into English, and other contributing factors need to be sought. 
Although the sample containing verbs of motion is not large enough to draw general conclusions, the number of shifts in perception with the effect of zooming out (one third of the total number of items) is sufficiently significant to indicate a tendency in the analyzed text. This can be further validated by looking into the occurrence of lexical items with the roots 'move' and 'place', both having their origin in verb-framed languages - not coding the manner and being marked by a highly schematic character.

In the whole text, there are 39 lexemes in the English version with the root 'move' featuring three word classes - verbs, nouns and adjectives. Apart from suffixes changing the word class, the prefix 're-' is used with the meaning 'away'. A comparison with the Slovak lexical items as their source language equivalents displays an array of 11 different roots combined with 8 different prefixes. Moreover, 14 out of the 39 source language analogues are marked by a higher level of specificity, e.g. 'vykroč-e-nie', literally 'up-step-ing' translated as 'moves' or 'vy-ber-a-nie', literally 'outtake-ing' translated as removing. Indeed, the sample suggests that the process of zooming out on the way from Slovak into English occurs in almost one third of the cases, which is comparable with the results described above. Obviously, apart from the tendency to zoom out, the levelling out in terms of lexical variety is also significant. Again, the root inventory reduction cannot be explained away by structural differences between the two languages, as English, being an analytical language whose lexicon draws on etymologically varied sources, displays relatively high root variability.

The root 'place' was identified in 23 lexical items of the English version of the text. Similarly to the word set defined by the root 'move', apart from suffixes changing the word class, only the prefix 're-' is used. The Slovak counterparts, on the other hand, are sourced by as many as 10 different roots, combined with a variety of 8 prefixes. The process of reducing the level of specificity, i.e. zooming out, concerns 9 Slovak-English pairs (e.g. 'za-mur-ova-nej', literally 'covered-by-wall-perfective-feminine' translated by 'placed' or 'vy-kroč-i-li', literally 'up-step-ed' translated as 'were placed'), which is slightly more than one third of the total. This means that a similar ratio has been arrived at via three different comparisons, which secures its high reliability.

Although both 'move' and 'place' are perfectly established and legitimate items of the English lexicon, there is no reason why the translator should not reach for solutions into the wealth of various English verbs representing motion, many of which belong to the layer of concrete short words of Anglo-Saxon origin. This would also be in closer equivalence with the more carnal imagery of the Slovak original.

Apart from the shifts identified in the verbs denoting motion, there is a set of verb shifts that can be described as prolonging emotional distance between the viewer and the event targeted. These cases are marked by neutralization in the sense that it involves the change of stylistic value to a more neutral, or conventional. This might involve a less expressive, less exotic or otherwise less emotionally charged representation of an event bearing consequences on the emotional layer of the construal in the reader's mind and body. In the analyzed sample, the phenomenon is manifested in the following cases: 
(10) a. L'udia vždy boli a sú pre ich postavenie mnoho obetovat', [...] ba dat' sa aj zabit'. b. People have always been prepared to sacrifice a lot for their creation, [...] even to die.

where the kind of death (letting oneself be killed), entailing violence and aggression is included in the Slovak word.

(11) a. od chvíle, ako sa sochy začali stavat', hned' sa začali aj búrat' a všelijako preinačovat'.

b. from the moment statues started to be built, they started to be demolished and modified in all sorts of ways.

where 'slightly and gradually' is missing in the English version, as well as the colloquial stylistic value of the Slovak lexeme, which underwrites folk associations, as opposed to the Latinate 'modify' with the learned stratum ramifications. As has already been suggested, such intellectualization leads to emotional detachment.

(12) a. Mnohé z nich sú už zabudnuté, spustnuté

b. Many of them have already been forgotten and abandoned

Interestingly, the Slovak participle denoting the state 'no longer taken care of; desolate' is translated as a motion verb in English, which does not immediately trigger an image related to the condition of the monuments. In terms of the focus of attention, the emotional aspects of 'forlorn' and 'desolate' are redirected towards a more neutral 'no longer visited', thus neutralizing the emotional charge associated with the image of the scene.

(13) a. Postupne vyplnili aj d'alšie dve strany udalost'ami dvadsiateho storočia.

b. They gradually filled a further two pages with events from the $20^{\text {th }}$ century.

In this example, the translator resists unconventional imagery is highly marked. While in the Slovak version, the word 'strany' refers to 'sides' in the most concrete spatial sense which are filled 'up' (made completely full as signalled by the prefix 'vy-' in the word 'vy-plnili'), the English translation not only fails to signal completeness, thus reducing the dramatic effect, but also the image of burghers in Spišská Sobota filling two sides of an object with 'events' is resisted by opting for a different meaning of the original polysemic expression, i.e. changing 'sides' into 'pages'. The scenery is thus, again, rationalized, now from the physical handling of the symbols to the intellectual process of writing.

(14) a. Kiežby čerstvé kvetiny vydržali pri pomníkoch až do najbližšej revolúcie v popmusic.

b. Let's hope that fresh flowers remain at the monuments until the next revolution in pop-music. 
Here, the meaning aspect 'against resistance' contained in the conceptual structure of the Slovak expression is deleted via using the more neutral 'remain' in English, thus taking the original emotional charge off.

(15) a. pri prechádzke v Postupime objavil som vo vzdialenom kúte parku podivné zhromaždenie.

b. on a walk through Postdam I came across a strange group in a remote corner of the park.

Although this time the value of the two verbs is not marked by any significant shift, as both the English and the Slovak lexical items express the manner in which the object was met, i.e. 'by accident', the example is worthwhile listing because of the placement of the particle 'som', which is marked in the Slovak clause. In an unmarked situation, it should appear before the main verb, i.e. 'v Postupime som objavil'. Its marked placement after the verb has archaic connotations and could be described as an instance of idiolect in Lipták's otherwise modern contemporary Slovak. Such treatment of the verb particles is systematic in the essay, and it is not compensated in the English translation in any way, thereby weakening the subjective element in the style of the author.

(16) a. miesto, kde filozofoval, muzicíroval, písal listy Voltairovi

b. the place where he philosophied, made music, wrote letters to Voltaire

Similarly to the example (11) above, the colloquial value of the Slovak lexeme is lost in the English version, which uses a neutral expression, thereby ignoring the 'homemade', 'informal' tinge inherent to the construal.

(17) a. suverénne tvrdenie, že Cyril a Metod práve tu, v Komárne "museli” prechádzat' cez Dunaj

b. confidently claimed that Cyril and Methodius had to have crossed the Danube precisely here

In this example, the confident claim by the authorities is undermined by quotation marks in the source text, cuing irony and thus a subjective view of the credibility of the authorities in question, which is completely deleted from the English version

Another set of lexical choices that can be associated with the move towards greater schematism is the tendency is to use Latinate expressions in situations where a synonymous Anglo-Saxon expression would be a relevant paradigmatic choice. Although the proportion of the words of Latinate origin in the English lexicon is greater than in its Slovak analogue, both languages profit from a layer of learned, abstract vocabulary that can be traced to the knowledge accumulated in the Greco-Roman world of the antiquity. These include: 'zastupovat" - 'represent'; 'búrat" - 'demolish'; 'preinačovat' - 'modify'; 'vznikat” - 'establish'; 'chýbat' - 'be absent'; 'pripomínat' 'commemorate'.

Indeed, in Slovak, most of the Latinate expressions are also readily available ('reprezentovat', 'demolovat", 'modifikovat", 'etablovat' sa', 'absentovat', 
'komemorácia'), and yet they were not selected, even though they would be considered unmarked in academic style. The English translation thus shifts the text towards a greater normalcy or conventionality in terms of genre to the detriment of preserving the carnality of the original text, although the latter is an important feature of the ideational make-up of Lipták's essay.

Last but not least, the imagery activated in the reader is normalized by means of shifting the agency to fit a more prototypical model of agenthood as applied in the framework of Western values defined by the qualities of animacy, intention, cause, and human (cf. MacWhinney, 1982: 217). Endowing inanimate objects with agency, however, is a common and natural linguistic phenomenon, an instantiation of grammatical metaphor. With regard to English, Bernárdez (2013) quoting Yang's (2008) study of grammatical metaphor across languages even concludes that

English, in a higher degree than many or most other languages, seems to be extremely fond of metaphor and metonymy using them when other languages would prefer a literal form of expression (Bernárdez, 2013: 314),

attributing this to the 'matter of culture'. Normalization of agency patterns in the examples quoted thus cannot be attributed to the resistance on the part of the target language structural make-up.

In the example (1) quoted above, the construal of the participants in the event is shifted on the way from Slovak to English, as the semantic element of 'human' is cognitively de-activated. While in the Slovak expression, the monuments are specifically construed as human beings which can be 'de-seat-ed' ('zo-sad-ený') from their plinths, the English verb 'removed' invites a construal with an inanimate participant, thereby re-configuring the monuments as inanimate objects.

In the example

(18) a. velili k útoku na všetky svetové strany

b. [they] signalled attack in all directions

the activity of 'commanding', largely a human capability, is ascribed to the statues in the Slovak version, and, again, conventionalized in the English translation by an expression that can entail inanimate participants. A similar pattern can be identified in the following example:

(19) a. po prevrate pribudol aj generál Štefánik

b. General Štefánik was added after the revolution

While in the original text an active structure is used and the personality appears of its own accord, the English translation assigns the semantic role of 'patient' to the statue, leaving the role of 'agent', though not overtly expressed, to a human actor.

Rather than to the structural differences, such conventionalization might be attributed to the lack of acceptability of ambiguous or even absurd imagery in the target culture genre equivalent. Another cultural determinant might be the varying degree of 
tolerance towards ambiguity in the presentation of facts, as claimed by Balaban (1999: 130)

Thoughts or actions that are inconsistent or contradictory are considered troubling in American society. These notions of agency map on to conceptions of mental health and illness in American culture, where there are folk beliefs that people are agents with coherent intentions.

In small nations such as the Slovak where people feel as patients rather than agents in terms of historical processes, the relevant folk beliefs may not be so strong.

\section{Conclusion}

Stripping an academic text of its 'poetic sources of meaning' in the process of translation into English as the language of globalization might be motivated by hegemonic appropriation of knowledge representation rather than being a natural process owing to translation universals and structural differences between languages and language families. In terms of specific linguistic patterns, the analysis demonstrated that the 'rationalizing' tendencies include producing distance by reducing specificity and materiality of the meaning construals, schematization, Latinization, levelling out of expressive meaning, as well as re-normalizing agenthood to match prototypical Western perceptions. As claimed by Berman (1995: 296), such tendencies

[a]re not ahistorical. [...] From the very beginning, western translation has been an embellishing restitution of meaning, based on the typically Platonic separation between spirit and letter, sense and word, content and form, the sensible from the non-sensible,

with the result that the translated text is "more "clear", more "elegant", more "fluent”, more "pure" than the original.' (Berman, 1995: 296-297).

Grounding the notion of translation equivalence in cognitive translatology with imagery as a tertium comparationis, it is argued that rather than appropriating translations to the functional requirements of the genre and its prestige in the target language culture, the translator should attempt to resist the hegemonic tendencies by staying confident to the original imagery underlying the meaning patterns, especially in cases such as the analyzed one, where 'scientific register' is not an explicit publication order.

\section{References}

Primary sources

Lipták, Lubomír (1999a): Storočie dlhšie ako sto rokov. Bratislava: Kalligram. 
Lipták, Lubomír (1999b): "Monuments of Political Changes and Political Changes of Monuments". (Translated by S. Miklošová) In Miro Kollár, ed., Scepticism and Hope. Bratislava: Kalligram, 110-163.

Secondary sources

Balaban, Victor (1999): "Self agency in religious discourse". In Raymond W. Gibbs Jr and Gerard J. Steen, eds., Metaphor in Cognitive Linguistics: Selected Papers from the 5th International Cognitive Linguistics Conference Amsterdam, 1997. Amsterdam and Philadelphia: John Benjamins, 125-144.

Balaskó, Maria (2008): "What does the figure show? Patterns of translationese in a Hungarian comparable corpus". Trans-kom, 1(1): 58-73.

Bennet, Karen (2007a): "Galileo's revenge: Ways of construing knowledge and translation strategies in the era of globalisation". Social Semiotics, 17(2): 171-193.

Bennet, Karen (2007b): "Epistemicide! The tale of a predatory discourse". The Translator, 13(2): 151-169.

Berman, Antoine (1995): Translation and the trial of the foreign (L. Venuti, trans.). In Lawrence Venuti, ed., The Translation Studies Reader. London and New York: Routledge, 385-297.

Bernárdez, Enrique (2013): “A Cognitive View of the Role of Culture in Translation”. In Ana Rojo and Iraide Ibarretxe-Antuñano, eds., Cognitive Linguistics and Translation. Advances in Some Theoretical Models and Applications. Berlin: Walter de Gruyter, 99-122.

Childs, Peter and Roger Fowler (2006): The Routledge Dictionary of Literary Terms. London and New York: Routledge.

Dayrell, Carmen (2007): "A quantitative approach to compare collocational patterns in translated and non-translated texts". International Journal of Corpus Linguistics, 12(3): 375414.

Findra, Ján (2004): Štylistika slovenčiny. Martin: Osveta.

Halliday, Michael K. (1994/2001): "The construction of knowledge in the grammar of scientific discourse, with reference to Charles Darwin's The Origin of Species". In Malcolm Coulthard, ed., Advances in Written Text Analysis. London: Routledge, 136-156.

Halverson, Sandra L. (2013): "Implications of cognitive linguistics for translation studies". In A. Rojo and I. Ibarretxe-Antuñano, eds, Cognitive Linguistics and Translation. Advances in Some Theoretical Models and Applications. Berlin: Walter de Gruyter, 33-74.

Hatim, Basil and Mason, Ian (1999): The Translator as Communicator. New York: Routledge. House, Juliane (2005): Translation. Oxford: OUP.

Jeffries, Lesley, McIntyre, Dan (2010): Stylistics. Cambridge: CUP.

Lakoff, George, Johnson, Mark (1999): Philosophy in the Flesh. The Embodied Mind and its Challenge to Western World. New York: Basic Books.

Langacker, Ronald W. (2009): Investigations in Cognitive Grammar. Berlin: Mouton de Gruyter.

Laviosa, Sara (1998): "Core patterns of lexical use in a comparable corpus of English narrative prose". Meta, 43 (4): 557-570.

MacWhinney, Brian (1982): "Functionalist approaches to grammar". In Eric Wanner and Lila R. Gleitman, eds., Language acquisition: The state of the art: Cambridge: CUP, 173-218.

Martín de Léon, Celia (2013): "Contributions of cognitive models of meaning to translation". In A. Rojo and I. Ibarretxe-Antuñano, eds., Cognitive Linguistics and Translation. Advances in Some Theoretical Models and Applications. Berlin: Walter de Gruyter, 99-122. 
Mauranen, Anna and Kujamäki, Tampere Pekka (2004): Translation Universals. Do They Exist? Amsterdam and Philadelphia: John Benjamins.

Muñoz Martín, Ricardo (2013): "The interference between cognitive linguistics and cognitive translatology". In Ana Rojo and Iraide Ibarretxe-Antuñano, eds., Cognitive Linguistics and Translation. Advances in Some Theoretical Models and Applications. Berlin: Walter de Gruyter, 75-98.

Peprník, Jaroslav (2000): "Lexical semantics". In Pavol Štekauer, ed., Rudiments of English Linguistics. Prešov: Slovacontact, 133-176.

Rojo, Ana (2002): “Applying frame semantics to translation”. Meta, 47(3): 312-350.

Rojo, Ana (2013): "Cognitive linguistics and translation studies: Past, present and future". In Ana Rojo and Iraide Ibarretxe-Antuñano, eds., Cognitive Linguistics and Translation. Advances in Some Theoretical Models and Applications. Berlin: Walter de Gruyter, 3-33.

Slobin, Dan (2000): "Verbalized events. A dynamic approach to linguistic relativity and determinism". In Susanne Niemeier and René Dirven, eds., Evidence for Linguistic Relativity. Amsterdam and Philadelphia: John Benjamins, 107-138.

Slobin, Dan (2007): "Language and thought online". In Vyvyan Evans, Benjamin K. Bergen and Jörg Zinken, eds., The Cognitive Linguistics Reader. Advances in Cognitive Linguistics. London: Equinox Publishing, 903-929.

Slovník súčasného slovenského jazyka (2006). Bratislava: Veda.

Snell-Hornby, Mary (1995): Translation Studies: An Integrated Approach. Amsterdam and Philadelphia: John Benjamins.

Sweetser, Eve (1990): From Etymology to Pragmatics. Metaphorical and Cultural Aspects of Semantics Structure. Cambridge: CUP.

Tabakowska, Elżbieta (2013): “(Cognitive) grammar in translation. Form as meaning”. In Ana Rojo and Iraide Ibarretxe-Antuñano, eds., Cognitive Linguistics and Translation. Advances in Some Theoretical Models and Applications. Berlin: Walter de Gruyter, 229-250.

Tymoczko, Maria (2002) "Connecting the two infinite orders. Research methods in translation studies". In T. Hermans, ed., Crosscultural Transgressions. Research Models in Translation Studies II. Historical and Ideological Issues. Manchester: St Jerome Publishing, 9-25.

Ungerer, Friedrich and Schmid, Hans-Jorg (1996): An Introduction to Cognitive Linguistics. Harlow: Pearson Education Limited.

Venuti, Lawrence (1995): The Translator's Invisibility. New York: Routledge.

Verschueren, Jef (2012): Ideology in Language Use: Pragmatic Guidelines for Empirical Research.

Webster's Third New International Dictionary of the English Language (1993). Cologne: Konemann.

Yang, Yanning (2008): "Typological interpretation of differences between Chinese and English in grammatical metaphor”. Language Sciences, 30(4): 450-478. 